\title{
Potassium humate and NPK application rates influence yield and economic performance of potato crops grown in clayey loam soils
}

\author{
Muhammad Idrees $^{1^{*}}$, Muhammad Akbar Anjum² and Javed Iqbal Mirza ${ }^{3}$ \\ ${ }^{1}$ Institute of Pure and Applied Biology, Bahauddin Zakariya University, Multan, Pakistan \\ ${ }^{2}$ Department of Horticulture, Bahauddin Zakariya University, Multan, Pakistan \\ ${ }^{3}$ Institute of Molecular Biology and Biotechnology, University of Lahore, Lahore, Pakistan
}

\section{Abstract}

Potassium humate is one of the alternate sources of organic matter for improving physico-chemical properties of soils, crop growth and yield. The study investigated the effect of using different rates of potassium humate with and without recommended inorganic fertilizers in clayey loam soil on yield and economics of potato production. Four field experiments were conducted during 2010-11 and 2011-12 by using four levels of each, NPK (0, 50, 75 and $100 \%$ recommended dose) and potassium humate $\left(0,8,12\right.$ and $\left.16 \mathrm{~kg} \mathrm{ha}^{-1}\right)$ in a randomized complete block design $(R C B D)$ with three replications. Tuber number, tuber fresh and dry weight and biological yield per hill, tuber yield per hectare and harvest index were significantly and positively affected by increasing level of NPK in both autumn and spring crops. Application of potassium humate significantly increased tuber fresh and dry weights (up to 10.95\% and 14.43\%; respectively), tuber yield (up to 10.96\%), biological yield (up to 8.46\%) and harvest index (up to 3.1) in both autumn and spring crops but improved tuber number per hill only in autumn crops. Application of full rate of NPK fertilizers with $16 \mathrm{~kg} \mathrm{ha}^{-1}$ potassium humate resulted in the highest tuber yield (19.749 tons ha-1). However, study results of benefit cost ratio indicated that application of NPK at 75\% of recommended dose with $16 \mathrm{~kg} \mathrm{ha}^{-1}$ potassium humate remained the most economical for potato growers.

Keywords: Benefit to cost ratio, inorganic fertilizers, humic acid, solanum tuberosum

\section{Introduction}

Potato (Solanum tuberosum L.) is a popular vegetable crop in Pakistan. It is acknowledged as a supplementary food resource because it reduces the pressure on cereal crops (Lodhi, 2004). Potato production plays a vital role in the economy of the country, particularly in Punjab province, where it accounts $5.7 \%$ of total vegetables cultivated area providing economic advantages as well as creating employment opportunities. It is grown annually on an area of more than 20 million hectares with a total production of more than 330 million tons worldwide (CIP, 2014). In Pakistan, the crop is planted on an area of 161.9 thousand hectares annually with a tuber yield of 3.507 million tons. Its average yield is about 21.66 tons per hectare, which is lower than that of developed countries (Anonymous, 2014). The main problems causing low production especially in Punjab region are unavailability of healthy seed, lack of irrigation water, ill-advised application of fertilizer, attack of early blight and viral diseases.

Soil is used as a basic medium for growing crops. Most of the soils in Pakistan contain less than $1 \%$ organic matter, thus have poor soil texture and structure. As a result, the activities of soil microorganisms as well as plant growth and yield are reduced. The chemical fertilizers used to compensate the fertility status of soil are very expensive for the farmers. Most of the trace elements become unavailable to the plants due to soil alkalinity caused by lack of organic matter. Therefore, it necessitates for rationale use of both traditional and non-traditional organic sources (Marinari et al., 2000). Humic substances can be used as alternate sources of organic matter to improve soil physico-chemical properties as well as crop growth and final yield (Ohta et al., 2004).

Inorganic macronutrients i.e. nitrogen $(\mathrm{N})$, phosphorus $(\mathrm{P})$ and potassium $(\mathrm{K})$ are required in large amounts for growth and development of plants. Nitrogen is a vital constituent of amino acids and proteins and an integral component of many substances like chlorophyll and many enzymes (Brady, 1990). According to Alva (2004), availability of nitrogen plays a key role in sustaining vegetative and reproductive growth balance of potato crop. Phosphorus is considered as a necessary plant nutrient. Generally, potatoes are cultivated in $\mathrm{P}$ rich soil containing about 1000- $2000 \mathrm{~kg} \mathrm{ha}{ }^{-1}$. Usually, plants require about $1 / 5$ to $1 / 10$ as much $\mathrm{P}$ as they do $\mathrm{N}$ and $\mathrm{K}$. However, the phosphate contents present in the soil are only about $1 / 20$ or even less as compared to nitrogen and potassium contents (Westermann et al., 1994). Application of $\mathrm{K}$ is one of the most important factors that influence the growth and productivity of potato as it plays an important role in translocation of sugars (Tisdale et al.,

\footnotetext{
*Email: midrees2009814@yahoo.com
} 
2001). Improvement in crop production by application of potassium fertilizer is mainly due to formation of large sized tubers or by increasing the number of tubers per plant or both (Abdel-Latif et al., 2011).

Humic substances play a key role in recycling of nutrients (MacCarthy, 2003). Humates are used in soil or sprayed on plants (foliar application) mainly because of their very high content of humic acids, ranging from 30 to $60 \%$ and can be taken up easily by the roots (Stevenson and Cole, 1999). Combining organic and mineral inputs has been realized as most economical for maize and soybean crops (Vanlauwe and Zingore, 2011). Therefore, the present study was planned to evaluate the efficacy of potassium humate (K. humate) applications to improve yield attributes and determine its synergistic effect with NPK on potato production. Further, to assess the most effective and economical combination of NPK and potassium humate for its better performance under agroclimatic conditions of Multan (Pakistan).

\section{Materials and Methods}

Four field trials (two for autumn and two for spring crops of potato) were carried out during two consecutive years (2010-11 and 2011-12) at the Vegetable Research Area, Department of Horticulture, Bahauddin Zakariya University, Multan using different treatment combinations of NPK $(\mathrm{F} 0=0, \mathrm{~F} 1=50, \mathrm{~F} 2=75$ and $\mathrm{F} 3=$ $100 \%$ recommended dose $)$ and potassium humate $(\mathrm{H} 0=$ $0, \mathrm{H} 2=8, \mathrm{H} 3=12$ and $\mathrm{H} 4=16 \mathrm{~kg} \mathrm{ha}^{-1}$ ) containing humic acid $50 \%$, potassium $\left(\mathrm{K}_{2} \mathrm{O}\right) 10 \%, \mathrm{pH} 10$ and solubility $90 \%$. Total 16 treatment combinations i.e. T1 $=\mathrm{F} 0 \mathrm{H} 0, \mathrm{~T} 2=\mathrm{F} 0 \mathrm{H} 1, \mathrm{~T} 3=\mathrm{F} 0 \mathrm{H} 2, \mathrm{~T} 4=\mathrm{F} 0 \mathrm{H} 3, \mathrm{~T} 5=$ $\mathrm{F} 1 \mathrm{H} 0, \mathrm{~T} 6=\mathrm{F} 1 \mathrm{H} 1, \mathrm{~T} 7=\mathrm{F} 1 \mathrm{H} 2, \mathrm{~T} 8=\mathrm{F} 1 \mathrm{H} 3, \mathrm{~T} 9=\mathrm{F} 2 \mathrm{H} 0$, $\mathrm{T} 10=\mathrm{F} 2 \mathrm{H} 1, \mathrm{~T} 11=\mathrm{F} 2 \mathrm{H} 2, \mathrm{~T} 12=\mathrm{F} 2 \mathrm{H} 3, \mathrm{~T} 13=\mathrm{F} 3 \mathrm{H} 0$, $\mathrm{T} 14=\mathrm{F} 3 \mathrm{H} 1, \mathrm{~T} 15=\mathrm{F} 3 \mathrm{H} 2$ and $\mathrm{T} 16=\mathrm{F} 3 \mathrm{H} 3$ were tested in all crops. The recommended dose of inorganic fertilizers for potato crop in the region is $\mathrm{N}=120, \mathrm{P}_{2} \mathrm{O}_{5}$ $=80$ and $\mathrm{K}_{2} \mathrm{O}=80 \mathrm{~kg} \mathrm{ha}^{-1}$, which was fulfilled by applying urea $(46 \% \mathrm{~N})$, single super phosphate $(18 \%$ $\left.\mathrm{P}_{2} \mathrm{O}_{5}\right)$ and sulphate of potash $\left(50 \% \mathrm{~K}_{2} \mathrm{O}\right)$, respectively. All the amounts of $\mathrm{P}_{2} \mathrm{O}_{5}$ and $\mathrm{K}_{2} \mathrm{O}$ were added to the soil during seed bed preparation. Whereas, $1 / 3$ of $\mathrm{N}$ and potassium humate doses were also mixed into the soil during seed bed preparation and the balance amounts of $\mathrm{N}$ and potassium humate were split into two doses and applied after 30 and 75 days of planting the crops. Physico-chemical investigation of the soil used for the experiments indicated that its texture was clayey loam (sand $33.2 \%$, silt $28.5 \%$ and clay $38.3 \%$ ) and had EC $2.01 \mathrm{dS}^{\mathrm{m}-1}, \mathrm{pH} 8.0$, organic matter $0.84 \%$, available phosphorus $17.94 \mathrm{mg} \mathrm{kg-1}$ and available potassium 240 $\mathrm{mg} \mathrm{kg}^{-1}$ as determined by a field test (Luttmerding et al.,
1990).

Plantations of seed tubers of potato cv. Cardinal were carried out in 3rd week of September during 2010 and 2011 for autumn crops. Regarding spring crops, seed tubers were planted in 2nd week of January, 2011 and 2012. The autumn and spring crops were harvested in 3rd week of January and the last week of April, respectively. The data collected during study included; number of tubers per hill, fresh and dry weights of tubers per hill, tubers yield per hectare and biological yield. Harvest index, expressed in \%age, was estimated by following the given formula.

Harvest index $(\%)=($ Fresh weight of tuber $($ gram per hill $)) /($ Biological yield (gram per hill $)) \times 100$

The data were analyzed by adopting randomized complete block design (RCBD) with factorial arrangement. Least significance difference (LSD) test was employed at a probability level of 5\% to compare the treatment means (Steel et al., 1996). For economic analysis, benefit to cost ratio was calculated for all the treatments using prevailing prices of inputs and potato tubers. $\mathrm{BCR}=($ Total income $) /($ Total cost $)$.

\section{Results}

\section{Yield attributes}

Application of NPK caused significant improvement in all the yield attributes i.e. number of tubers per hill, fresh and dry weights of tubers per hill and tuber yield per hectare of autumn as well as spring crops. The minimum values of number of tubers per hill (4.54 in autumn and 5.68 in spring crops) were obtained when no NPK $(0 \%$ of recommended dose) was applied, while higher values for number of tubers $(4.75 \& 4.86$ in autumn and $7.82 \& 8.26$ in spring crops respectively) were recorded with the application of higher and intermediate NPK levels i.e. $100 \%$ and $75 \%$ of the recommended doses. These two treatments remained statistically at par. Fresh and dry weights of tubers per hill and tuber yield per hectare were significantly improved with increasing NPK level. NPK application at its $100 \%$ recommended dose gave the highest fresh (441.20 $\mathrm{g}$ in autumn and $372.62 \mathrm{~g}$ in spring crops) and dry weights $(85.442 \mathrm{~g}$ in autumn and $78.508 \mathrm{~g}$ in spring crops) of tubers per hill, and tuber yield per hectare (19.219 tons from autumn and 16.231 tons from spring crops). Whereas, the lowest values (14.609 \& 10.486 tons ha ${ }^{-1}$ from autumn and spring crops respectively) of all these attributes were recorded in the non-treated plants (Tables 1, 2).

In autumn crops, number of tubers per hill was significantly affected by different levels of potassium humate 
Table 1: Effect of varying levels of NPK and K. humate on yield attributes of potato cv. Cardinal autumn crops

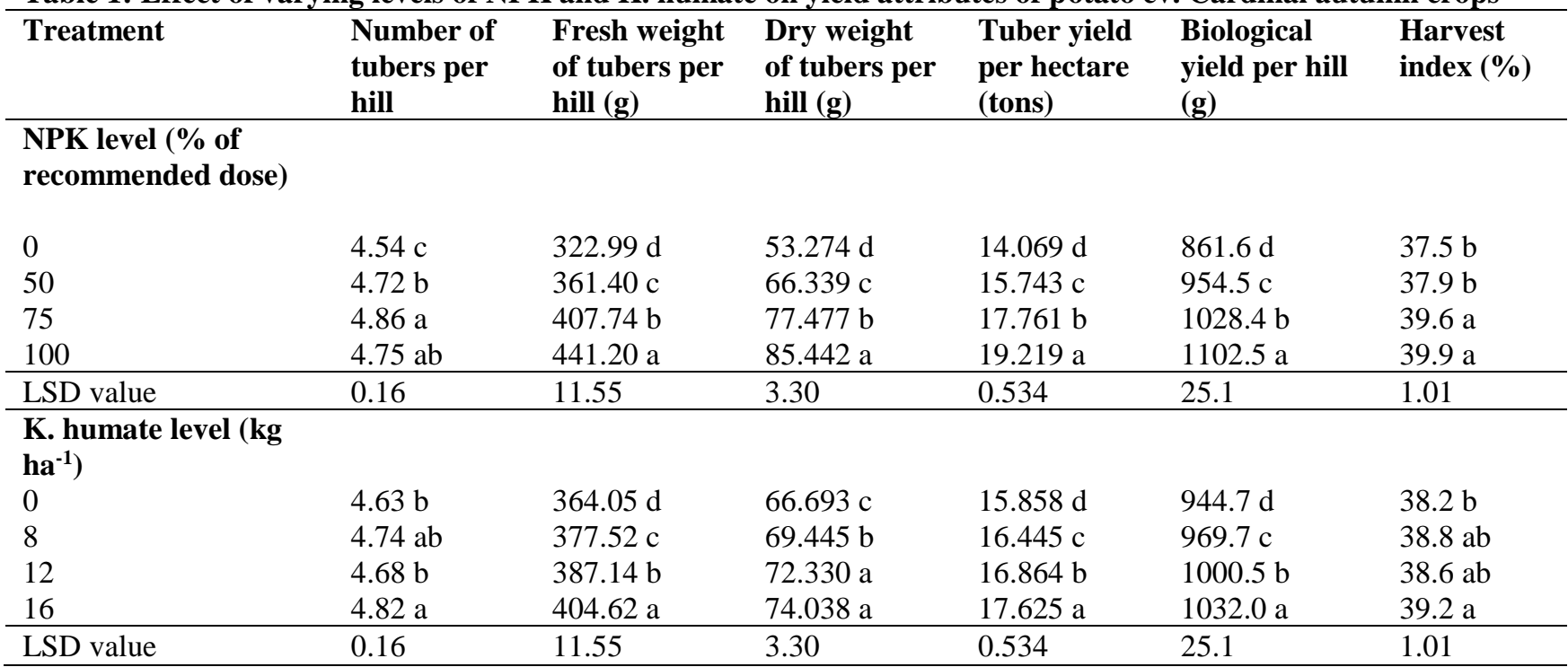

*Mean with different letter(s) for a group are statistically significant at $p \leq 0.05$ (LSD test).

Table 2: Effect of varying levels of NPK and K. humate on yield attributes of potato cv. Cardinal spring crops

\begin{tabular}{lllllll}
\hline Treatment & $\begin{array}{l}\text { Number of } \\
\text { tubers per } \\
\text { hill }\end{array}$ & $\begin{array}{l}\text { Fresh weight } \\
\text { of tubers per } \\
\text { hill }(\mathbf{g})\end{array}$ & $\begin{array}{l}\text { Dry weight } \\
\text { of tubers per } \\
\text { hill }(\mathbf{g})\end{array}$ & $\begin{array}{l}\text { Tuber yield } \\
\text { per hectare } \\
\text { (tons) }\end{array}$ & $\begin{array}{l}\text { Biological } \\
\text { yield per hill } \\
(\mathbf{g})\end{array}$ & $\begin{array}{l}\text { Harvest } \\
\text { index }(\%)\end{array}$ \\
\hline $\begin{array}{l}\text { NPK levels }(\% \text { of } \\
\text { recommended dose) }\end{array}$ & & & & & & \\
& & & & & & \\
0 & & & & & & \\
50 & $5.68 \mathrm{c}$ & $240.70 \mathrm{~d}$ & $40.075 \mathrm{~d}$ & $10.486 \mathrm{~d}$ & $557.33 \mathrm{~d}$ & $43.2 \mathrm{~b}$ \\
75 & $7.24 \mathrm{~b}$ & $293.30 \mathrm{c}$ & $58.485 \mathrm{c}$ & $12.776 \mathrm{c}$ & $683.79 \mathrm{c}$ & $43.1 \mathrm{~b}$ \\
100 & $8.26 \mathrm{a}$ & $340.29 \mathrm{~b}$ & $70.234 \mathrm{~b}$ & $14.823 \mathrm{~b}$ & $747.85 \mathrm{~b}$ & $45.4 \mathrm{a}$ \\
& $7.82 \mathrm{ab}$ & $372.62 \mathrm{a}$ & $78.508 \mathrm{a}$ & $16.231 \mathrm{a}$ & $802.54 \mathrm{a}$ & $46.4 \mathrm{a}$ \\
\hline LSD value & & & & & \\
\hline K. humate levels $(\mathbf{k g}$ & 1.19 & 12.78 & 2.908 & 0.556 & & \\
ha-1) & & & & & & \\
0 & 6.67 & $295.00 \mathrm{c}$ & $58.298 \mathrm{~d}$ & $12.850 \mathrm{c}$ & $675.37 \mathrm{c}$ & $43.7 \mathrm{~b}$ \\
8 & 7.05 & $304.78 \mathrm{c}$ & $62.199 \mathrm{c}$ & $13.276 \mathrm{c}$ & $680.86 \mathrm{c}$ & $44.6 \mathrm{ab}$ \\
12 & 7.49 & $315.84 \mathrm{~b}$ & $64.678 \mathrm{~b}$ & $13.758 \mathrm{~b}$ & $703.78 \mathrm{~b}$ & $44.7 \mathrm{a}$ \\
16 & 7.81 & $331.29 \mathrm{a}$ & $68.127 \mathrm{a}$ & $14.431 \mathrm{a}$ & $731.50 \mathrm{a}$ & $45.1 \mathrm{a}$ \\
\hline LSD value & 1.19 & 12.78 & 2.908 & 0.556 & 24 & 1.02 \\
\hline
\end{tabular}

*Mean with different letter(s) for a group are statistically significant at $p \leq 0.05$ (LSD test).

applied. The plants fertilized with potassium humate @ $16 \mathrm{~kg}$ ha $^{-1}$ gave the highest (4.82), while those grown without potassium humate produced the lowest number of tubers per hill (4.63). Fresh and dry weights of tubers per hill and tubers yield per hectare of autumn as well as spring crops were also significantly affected by potassium humate application (fresh weights varied from 364.05 to 404.62 $\mathrm{g}$ in autumn crops while, 295 to $331.29 \mathrm{~g}$ in spring crops, similarly dry weights ranged from 66.693 to
$74.083 \mathrm{~g}$ in autumn and from 58.298 to $68.127 \mathrm{~g}$ in spring crops). Increase in potassium humate application resulted in steady improvement in all the above mentioned parameters (Tables 1,2).

The combined application of NPK and potassium humate significantly improved fresh and dry weights of tubers per hill and tuber yield per hectare. The lowest fresh and dry weights (309.08 \& $48.394 \mathrm{~g} / \mathrm{hill}$ from autumn and 


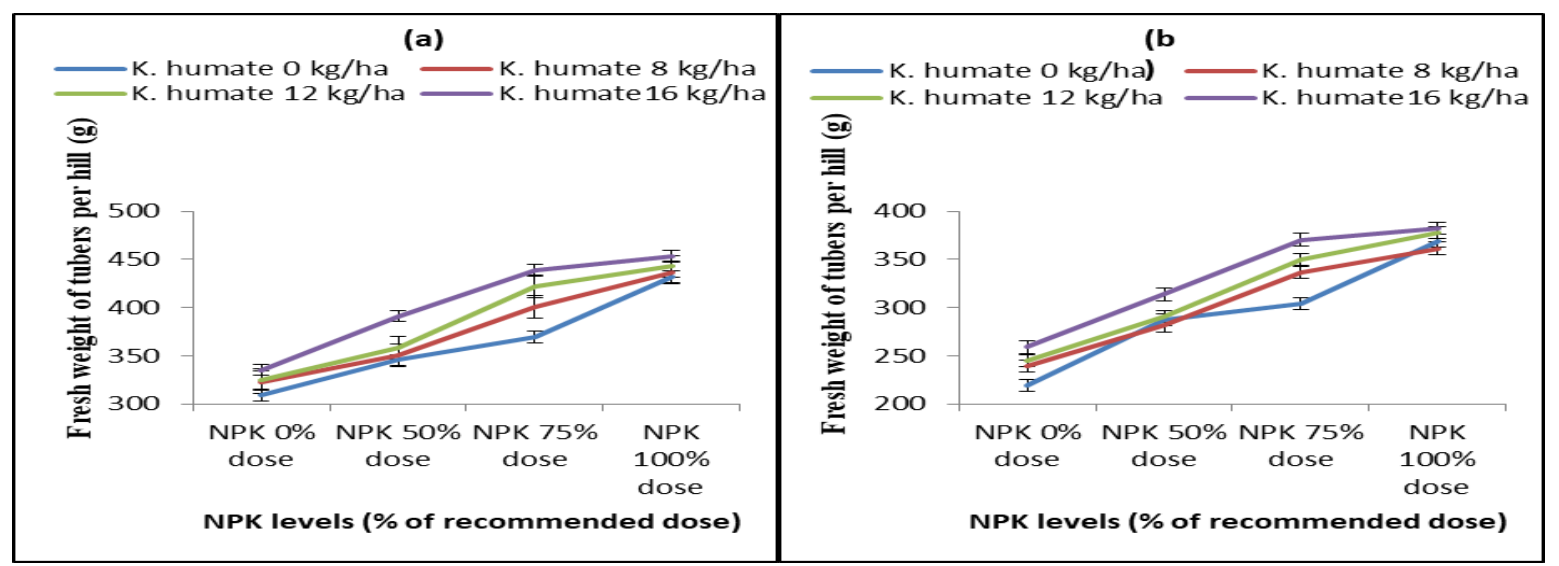

Figure 1: Effect of NPK and K. humate levels on fresh weights of tubers per hill (a) autumn crop (b) spring crop

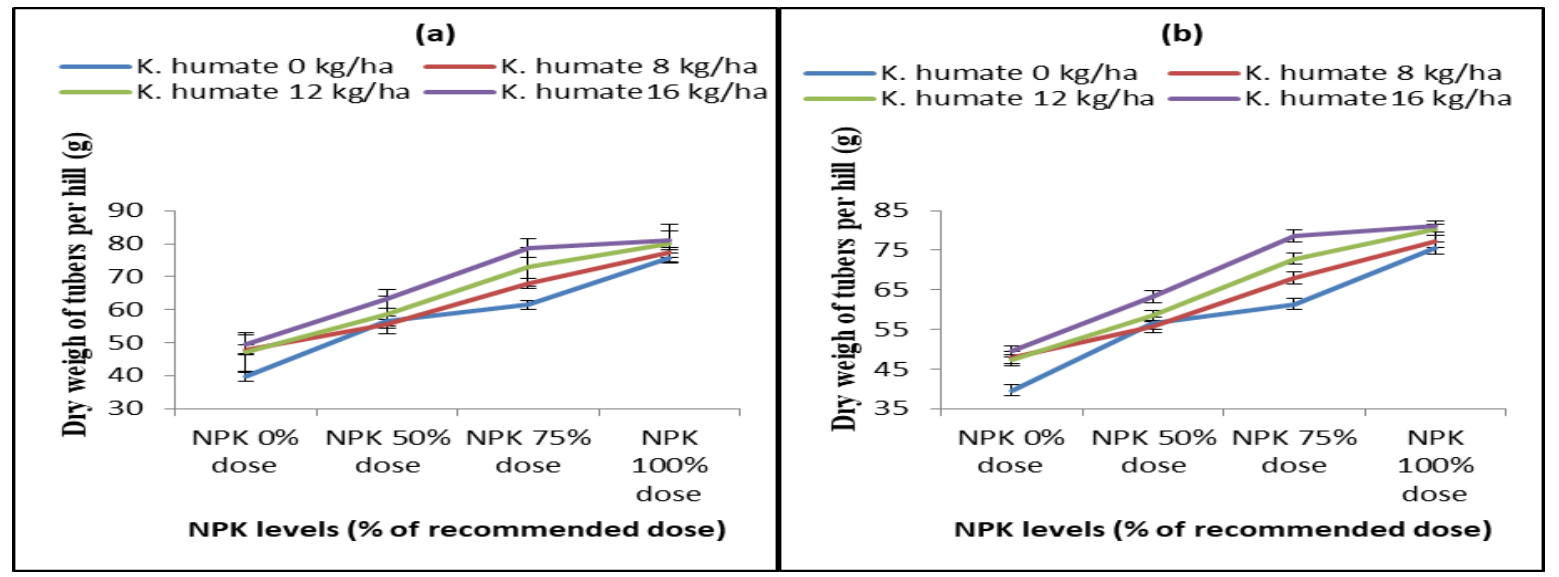

Figure 2: Effect of NPK and K. humate levels on dry weights of tubers per hill (a) autumn crop (b) spring crop

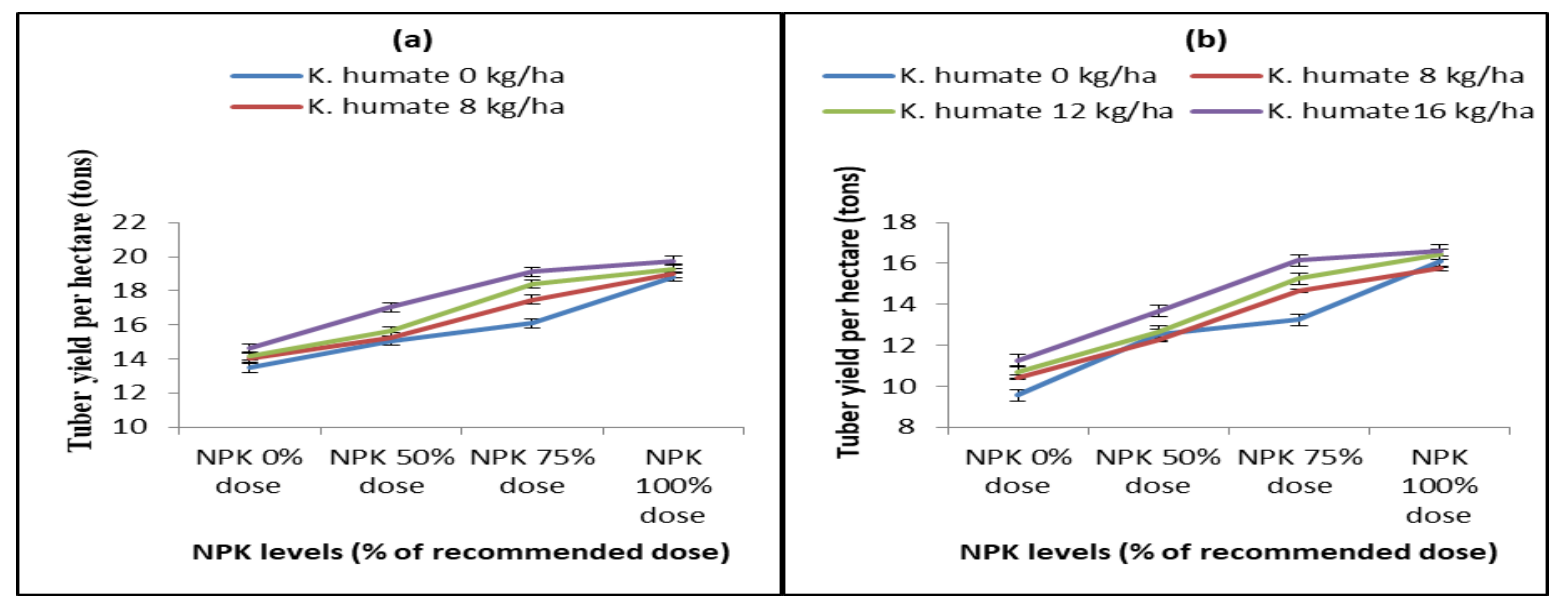

Figure 3: Effect of NPK and K. humate levels on tubers yield per hectare (a) autumn crop (b) spring crop

$219.54 \& 39.646 \mathrm{~g} / \mathrm{hill}$ from spring crops) and tuber yield per hectare (13.464 \& 9.563 tons from autumn and spring crops, respectively) were observed in control which increased when both NPK and potassium humate were 
applied together (up to19.749 and 16.639 tons from autumn and spring crops) (Figure 1-3).

\section{Biological yield and harvest index}

NPK caused significant improvement in biological yield and harvest index (Tables 1, 2). Full dose of NPK resulted in maximum biological yield $(1102.5 \& 802.54$
$43.2 \%$ from spring crops) was estimated under no application of inorganic fertilizers.

Application of potassium humate significantly improved biological yield as well as harvest index (Tables 1, 2). The maximum biological yield i.e. $1032 \mathrm{~g}$ per hill as well as harvest index $39.2 \%$ were recorded in

Table 3: Profitability per hectare of $S$. tuberosum L. autumn crops under varying levels of NPK and K. humate

\begin{tabular}{llllll}
\hline $\begin{array}{l}\text { NPK level } \\
\text { recommended dose) }\end{array}$ & K. humate (kg ha-1) & Total cost (US\$) & Total income (US\$) & Net benefit (US\$) & BCR \\
\hline 0 & 0 & $1,734.68$ & $2,234.34$ & 499.66 & 1.29 \\
0 & 8 & $1,754.68$ & $2,317.64$ & 562.96 & 1.32 \\
0 & 12 & $1,764.68$ & $2,341.14$ & 576.46 & 1.33 \\
0 & 16 & $1,774.68$ & $2,414.08$ & 639.40 & 1.36 \\
50 & $1,914.60$ & $2,393.04$ & 478.44 & 1.25 \\
50 & 8 & $1,934.60$ & $2,519.62$ & 585.02 & 1.30 \\
50 & 8 & $1,944.60$ & $2,579.78$ & 635.18 & 1.33 \\
50 & 12 & $1,954.60$ & $2,814.76$ & 860.16 & 1.44 \\
75 & 16 & $2,004.57$ & $2,659.15$ & 654.58 & 1.33 \\
75 & 0 & $2,024.56$ & $2,888.65$ & 864.09 & 1.43 \\
75 & 8 & $2,034.56$ & $3,039.57$ & $1,005.01$ & 1.49 \\
75 & 12 & $2,044.56$ & $3,159.35$ & $1,114.79$ & 1.55 \\
100 & 16 & $2,094.52$ & $3,110.40$ & $1,015.88$ & 1.48 \\
100 & 0 & $2,114.52$ & $3,145.75$ & $1,031.23$ & 1.49 \\
100 & 8 & $2,124.52$ & $3,187.06$ & $1,062.54$ & 1.50 \\
100 & 12 & $2,134.52$ & $3,265.42$ & $1,130.90$ & 1.53 \\
\hline
\end{tabular}

Table 4: Profitability per hectare of $S$. tuberosum L. spring crops under varying levels of NPK and K. humate

\begin{tabular}{|c|c|c|c|c|c|}
\hline $\begin{array}{l}\text { NPK level (\% of } \\
\text { recommended dose) }\end{array}$ & K. humate (kg ha-1) & Total cost (US\$) & Total income (US\$) & Net benefit (US\$) & BCR \\
\hline 0 & 0 & $3,083.80$ & $2,442.87$ & -640.93 & 0.79 \\
\hline 0 & 8 & $3,103.80$ & $2,677.34$ & -426.46 & 0.86 \\
\hline 0 & 12 & $3,113.80$ & $2,735.10$ & -378.70 & 0.88 \\
\hline 0 & 16 & $3,123.80$ & $2,887.91$ & -235.89 & 0.92 \\
\hline 50 & 0 & $3,260.45$ & $3,179.12$ & -81.33 & 0.98 \\
\hline 50 & 8 & $3,280.45$ & $3,143.74$ & -136.71 & 0.96 \\
\hline 50 & 12 & $3,290.45$ & $3,251.55$ & -38.90 & 0.99 \\
\hline 50 & 16 & $3,300.45$ & $3,503.36$ & 202.91 & 1.06 \\
\hline 75 & 0 & $3,348.78$ & $3,396.75$ & 47.97 & 1.01 \\
\hline 75 & 8 & $3,368.78$ & $3,760.81$ & 392.03 & 1.12 \\
\hline 75 & 12 & $3,378.78$ & $3,911.90$ & 533.12 & 1.16 \\
\hline 75 & 16 & $3,388.78$ & $4,139.73$ & 750.95 & 1.22 \\
\hline 100 & 0 & $3,437.10$ & $4,126.65$ & 689.55 & 1.20 \\
\hline 100 & 8 & $3,457.10$ & $4,040.96$ & 583.86 & 1.17 \\
\hline 100 & 12 & $3,467.10$ & $4,219.45$ & 752.35 & 1.22 \\
\hline 100 & 16 & $3,477.10$ & $4,267.23$ & 790.13 & 1.23 \\
\hline
\end{tabular}

$\mathrm{g} / \mathrm{hill}$ in autumn and spring crops, respectively) and also the highest harvest index $(39.9 \%$ from autumn \& $46.4 \%$ from spring crops). While, the minimum biological yield (861.6 \& $557.33 \mathrm{~g} / \mathrm{hill}$ in autumn and spring crops, respectively) and harvest index $(37.5 \%$ from autumn \& the plants having application of highest level of potassium humate $\left(16 \mathrm{~kg} \mathrm{ha}^{-1}\right)$ compared to control (biological yield $=944.7 \mathrm{~g} / \mathrm{hill}$ and harvest index $=$ $38.2 \%$ ). The combined application of potassium humate and NPK fertilizers although significantly affected 
biological yield but failed to induce significant impact on harvest index (Figure 4).

\section{Economic analysis}

Economic analysis of autumn crops showed that application of NPK and potassium humate resulted in
NPK fertilizers in both autumn and spring crops. The increase in these parameters is well reported by (Yourtchi et al. 2013). Application of NPK results in increased starch accumulation and encourages tuber formation. It also enhances duration of tuber bulking that leads to increased crop yield. Tuber yield in potato is

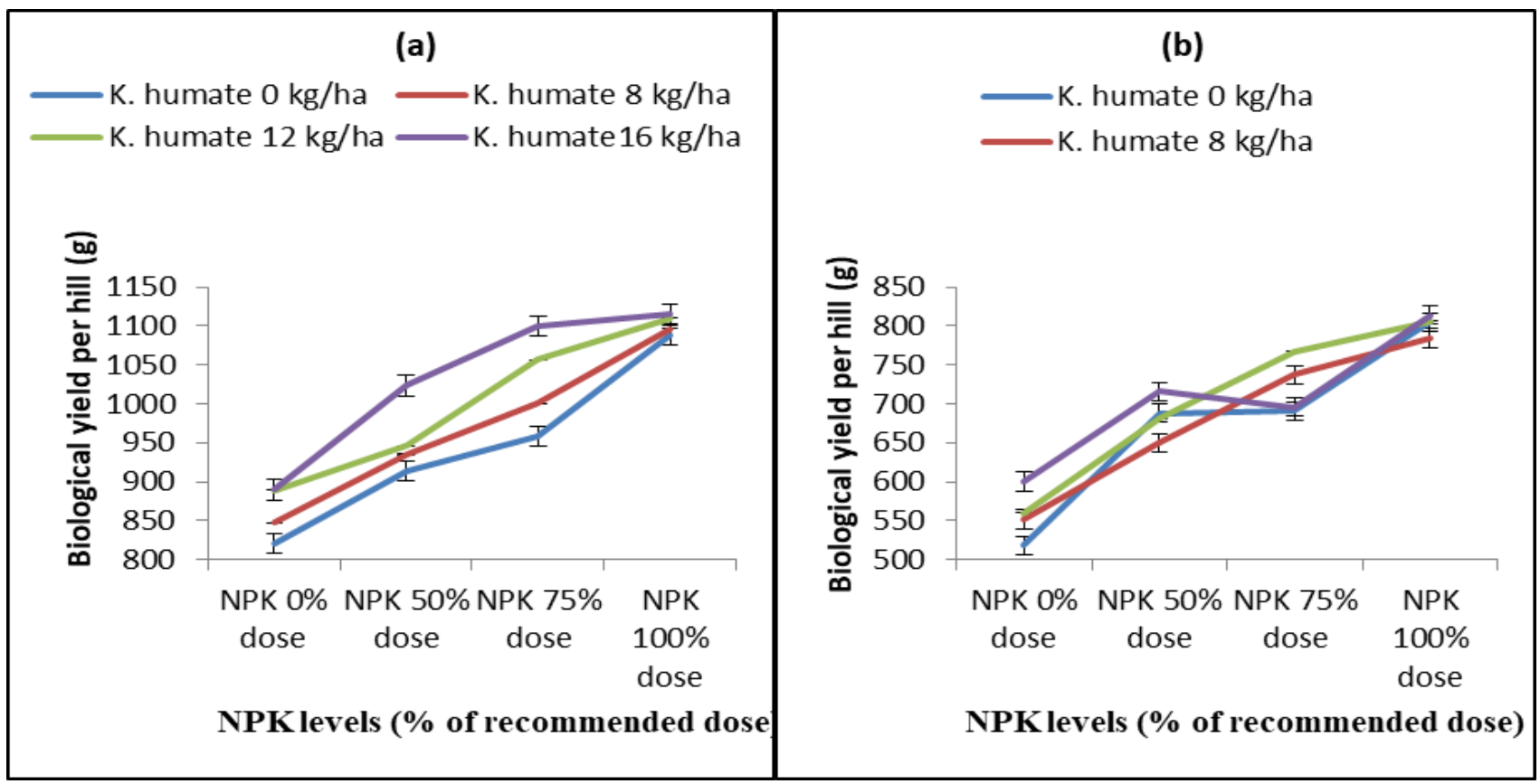

Figure 4: Effect of NPK and K. humate levels on biological yield per hill (a) autumn crop (b) spring crop

higher benefit cost ratio (BCR) due to more income compared to that of control. Application of intermediate dose $(75 \%$ of recommended dose) of NPK coupled with higher level of potassium humate $(16 \mathrm{~kg}$ ha-1) gave the maximum BCR value (1.55). The plants to which no NPK and / or potassium humate were applied resulted in smaller $\mathrm{BCR}$ values due to lower net benefits (Table 3 ).

In Pakistan, higher production cost and low yield are main limiting factors for potato especially spring crop grown in plains. BCR assessment demonstrated that growing of spring crop of potato without NPK fertilization is not economical. However, a steady improvement in potato yield was noticed by the combined application of NPK and potassium humate. Application of full dose (100\% of recommended dose) of NPK $+16 \mathrm{~kg}$ potassium humate $\mathrm{ha}^{-1}$ gave the maximum BCR value. The plants receiving no fertilizers resulted in the lowest income and ultimately the minimum BCR value i.e. 1.29 (Table 3).

\section{Discussion}

In the present study, all the yield attributes, harvest index and BCR values increased due to application of directly related with reasonable availability of $\mathrm{N}, \mathrm{P}$ and $\mathrm{K}$ in the soil and their uptake by the plants. Application of $\mathrm{N}$ delays leaf senescence, thereby increasing the leaf area duration and improves tuber yield (Zelalem et al. 2009). Furthermore, application of $N$ to potato crop prior to tuber initiation enhances the growth and development of vegetative parts of plant. Ultimately, it produces increased number of tubers per plant that results in higher tubers fresh weight (Kanzikwera et al., 2001). According to Lemaga and Caesar (1990), application of $\mathrm{N}$ to potato crop resulted in more stolon formation by affecting the biosynthesis and sustaining hormonal balance, particularly gibberellins, cytokinins and abscissic acid. Similarly, Yourtchi et al. (2013) also observed variation in number of potato tubers under different levels of $\mathrm{N}$ application. Application of $\mathrm{P}$ and $\mathrm{K}$ also caused improvements in yield attributes of potato. Phosphorus is an essential constituent of organic compounds such as phospholipids, phosphoproteins and nucleic acids (Marschner, 1995). Similarly, potassium plays a vital role in energy status, translocation, storage of carbohydrates and maintaining tissue water relation (Berisha et al., 2014). The current results are in line with 
those of Alam et al. (2007) and Guler (2009), who obtained higher tuber yields of potato by increasing NPK application rates.

Potassium humate markedly increased tuber number and also had positive effects on other yield attributes, biological yield and benefit cost ratio. It enhances plant growth and development by improving soil texture, thereby increasing the penetration capacity of root into the soil which increases uptake of water by the plants. Humic acids play a beneficial role in freeing up nutrients in the soil to make them available to the plants as they need, it also increases soil water holding capacity (Mackowiak et al., 2001). It also increases performance of microorganisms present in the soil, improves physical and chemical properties of the soil that positively affect the plant yield (Tisdale et al., 2001). The positive effects of potassium humate on potato crops in the present study are in accordance with those reported for many other crops by Chen and Aviad (1990). Albayrak (2005) found that all major yield attributes of Brassica rapa were significantly improved by the application of humic acids. These effects were more beneficial when these were applied in lower concentrations. Application of potassium humate @ 4 to 30 $\mathrm{kg} \mathrm{ha}^{-1}$ to the soil resulted in the best results (Pilanah and Kaplan, 2003). Similar effects of potassium humate application have also been reported in wheat (Tonder, 2008), tomato (Verlinden et al., 2009), hot pepper (Ghoname et al., 2009), potato (Ezzat et al., 2009) and soybean and black gram (Patil et al., 2011).

Significant increase in fresh and dry weights of potato tubers and also the biological yields might be due to physiological role of NPK fertilizers and potassium humate because application of humic substances in the presence of NPK fertilizers improved the organic carbon content of soil up to $0.05 \%$ and cation exchange capacity of soil by $18 \%$. An increase in nutrient absorption by onion plant was also reported by (Sangeetha et al. 2006) under combined application of humic acid and inorganic fertilizers. Organic amendments in combination with inorganic fertilizers are the best soil additive to improve water use efficiency (Dass et al., 2008). According to (Sangeetha et al. 2006), when humic acid was applied @ $20 \mathrm{~kg} \mathrm{ha}^{-1}$ in combination with full recommended dose of NPK to onion crop, it resulted in highest bulb yield with $12 \%$ increase over the yield obtained with recommended dose of NPK only.

Potassium humate decreased the requirement of inorganic fertilizer as the maximum cost benefit ratio in autumn crop was computed when $16 \mathrm{~kg}$ potassium humate was applied with $75 \%$ of NPK recommended dose. These results are also partially supported by Dass et al. (2008), who also obtained the best results in terms of yield and net economic return of Brassica oleracea and Capsicum annum crops under application of 50\% less NPK with organic fertilizers. According to Khan et al. (2010), the application of humic acid in combination with a 50\% less NP chemical fertilizers caused 24 to $47 \%$ increase in grain yield over the control and saved valuable high-cost chemical fertilizers.

\section{Conclusion}

It is obvious from the results that application of NPK significantly increased tuber yield of potato $\mathrm{cv}$. Cardinal in the presence of potassium humate due to their synergistic effect. Although, all combinations of NPK and potassium humate significantly improved yield attributes compared to alone application of NPK fertilizers but application of $75 \%$ of NPK recommended dose coupled with $16 \mathrm{~kg}$ potassium humate per hectare was the most suitable combination because it was found more economical combination among all the treatment combinations. Thus, nutshell of the study is that application of NPK fertilizers along with potassium humate is more profitable and economical for potato growers than alone application of inorganic fertilizers as it enhanced the efficiency of fertilizers, crop yield and net return.

\section{Acknowledgement}

The authors are highly grateful to Higher Education Commission (HEC), Islamabad for the financial support to carry out this research.

\section{References}

Abdel-Latif, K.M., E.A.M. Osman, R. Abdullah and N. Abdel-Kader. 2011. Response of potato plants to potassium fertilizer rates and soil moisture deficit. Advances in Applied Science Research 2: 388-397.

Alam, M.N., M.S. Jahan, M.K. Ali, M.A. Ashraf and M.K. Islam. 2007. Effect of vermicompost and chemical fertilizers on growth, yield and yield components of potato in Barind soils of Bangladesh. Journal of Applied Sciences Research 3: 1879-1888.

Albayrak, S.C. 2005. Effects of different levels and application times of humic acid on root and leaf yield and yield components of forage turnip (Brassica rapa L.). Journal of Agronomy 4:130-133.

Alva, A. 2004. Potato nitrogen management. Journal of Vegetable Crop Production 10: 97-130.

Anonymous. 2014. Pakistan Economic Survey 2013-2014. Ministry of Finance, Government of Pakistan, Islamabad. pp. 24-41.

Berisha, D., E. Susaj, N. Bardhi, L. Susaj, V. Havolli, S. Aliu, I. Rusinovci, B. Neziraj and A. Osmanaj. 2014. Effect of potassium fertilization rate on several vegetative and yield characters of potato (Solanum 
tuberosum L.), grown under two different agro-climatic regions of Kosovo. Online International Interdisciplinary Research Journal 4: 62-69.

Brady, N.C. 1990. The Nature and Properties of Soils, $10^{\text {th }}$ Ed. Macmillan Publishing Co., New York. pp. 279313.

Chen, Y. and T. Aviad. 1990. Effects of humic substances on plant growth. In: P. MacCarthy, C.E. Clapp, R.L. Malcolm and P.R. Bloom (eds.). Humic Substances in Soil and Crop Science. American Society of Agronomy and Soil Society of America, Madison, WI. pp. 161186.

CIP. 2014. Global Potato Research for a Changing World. International Potato Center (CIP), Lima, Peru. pp. 125.

Dass, A., N.K. Lenka, U.S. Patnaik and S. Sudhishri. 2008. Integrated nutrient management for production, economics and soil improvement in winter vegetables. International Journal of Vegetable Science 14:104120.

Ezzat, A.S., U.M. Saifel-Deen and A.M. Abdel-Hameed. 2009. Effect of irrigation water quantity, antitranspirant and humic acid on growth, yield, nutrients and water use efficiency of potato (Solanum tuberosum L.). Journal of Agricultural Science, Mansoura University 34: 11585-11603.

Ghoname, A.A., G. Mona, G.S.R. Dawood and W.A. ElTohamy. 2009. Effect of nitrogen forms and biostimulants foliar application on the growth, yield and chemical composition of hot pepper grown under sandy soil conditions. Research Journal of Agriculture and Biological Sciences 5: 840-852.

Guler, S. 2009. Effects of nitrogen on yield and chlorophyll of potato (Solanum tuberosum L.) cultivars. Bangladesh Journal of Botany 38: 163-169.

Kanzikwera, R.C., J.S. Tenywa, D.S.O. Osiru, E. Adipala and A.S. Bhagsari. 2001. Interactive effect of nitrogen and potassium on dry matter and nutrient partitioning in true potato seed mother plants. African Crop Science Journal 9: 127-146.

Khan, R., A. Rashid, M.S. Khan and E. Ozturk. 2010. Impact of humic acid and chemical fertilizer application on growth and grain yield of rain-fed wheat (Triticum aestivum L.). Pakistan Journal of Agricultural Research 23: 113-121.

Lemaga, B. and K. Caesar. 1990. Relationships between numbers of main stems and yield components of potato as influenced by different day lengths. Potato Research 33: 257-267.

Lodhi, M.K. 2004. Biological control of different soil born fungal diseases of potato (Solanum tuberosum L.) raised through tissue culture by using vesicular arbuscular mycorrhiza and other antagonistic fungi. $\mathrm{Ph} . D$. thesis. University of the Punjab, Lahore.

Luttmerding, H.A., D.A. Demarchi, D.V. Meidinger and T. Vold. 1990. Describing Ecosystems in the Field, $2^{\text {nd }}$ Ed. Victoria: British Columbia Ministry of Forest and Range and British Columbia Ministry of Environment.

MacCarthy, P. 2003. Humic substances: What we know and what we don't know. Symposium on Natural Organic Matter in Soils and Water, 22 ${ }^{\text {nd }}$ March, 2003. Iowa State University, Ames, Iowa, USA.

Mackowiak, C.L., P.R. Grossl and B.G. Bugbee. 2001. Beneficial effects of humic acids on micronutrients availability to wheat. Soil Science Society of America Journal 65: 1744-1750.

Marinari, S., G. Masciandaro, B. Ceccanti and S. Grego. 2000. Influence of organic and mineral fertilizers on soil biological and physical properties. Bioresource Technology 72: 9-17.

Marschner, H. 1995. Mineral Nutrition of Higher Plants, $2^{\text {nd }}$ Ed. Academic Press, Inc., San Diego. pp. 886-889.

Ohta, K., S. Morishita, K. Suda, N. Kobayashi and T. Hosoki. 2004. Effects of chitosan soil mixture treatment in the seedling stage on the growth and flowering of several ornamental plants. Journal of the Japanese Society for Horticultural Science 73: 66-68.

Patil, R.B., A.S. Kadam and S.S. Wadje. 2011. Role of potassium humate on growth and yield of soybean and black gram. International Journal of Pharma and Bio Sciences 2: 242-246.

Pilanah, N. and M. Kaplan. 2003. Investigation of effects on nutrient uptake of humic acid applications of different forms to strawberry plant. Journal of Plant Nutrition 26: 835-843.

Sangeetha, M., P. Singaram and R.U. Devi. 2006. Effect of lignite humic acid and fertilizers on the yield of onion and nutrient availability. $18^{\text {th }}$ World Congress of Soil Science, July 9-15, 2006. International Union of Soil Sciences, Philadelphia, Pennsylvania, USA.

Steel, R.G.D., J.H. Torrie and D.A. Dickey. 1996. Principles and Procedures of Statistics. McGraw Hill Book Co., New York, USA.

Stevenson, F.J. and M.A. Cole. 1999. Cycles of Soil: Carbon, Nitrogen, Phosphorus, Sulpher and Micronutrients, $2^{\text {nd }}$ Ed. John Wiley and Sons, New York.

Tisdale, S.L., W.L. Nelson and J.D. Beaton. 2001. Soil Fertility and Fertilizers. Macmillan Publishing Company, New York, pp. 249-291.

Tonder, J.T.V. 2008. Effect of potassium humate on soil properties and growth of wheat. M.Sc thesis. University of the Free State Bloemfontein, South Africa. $41 \mathrm{p}$. 
Vanlauwe, B. and S. Zingore. 2011. Integrated soil fertility management. An operational definition and consequences for implementation and dissemination. Better Crops 95: 4-7.

Verlinden, G., B. Pycke, J. Mertens, F. Debersaques, K. Verheyen, G. Baert, J. Bries and G. Haesaert. 2009. Application of humic substances results in consistent increases in crop yield and nutrient uptake. Journal of Plant Nutrition 32: 1407-1426.

Westermann, D.T., S.M. Bosma and M.A. Kay. 1994. Nutrient concentration relationships between the fourth petiole and upper stem of potato plants. American Potato Journal 71: 817-828.
Yourtchi, M.S., M.H.S. Hadi and M.T. Darzi. 2013. Effect of nitrogen fertilizer and vermicompost on vegetative growth, yield and NPK uptake by tuber of potato (Agria cv.). International Journal of Agriculture and Crop Sciences 18: 2033-2040.

Zelalem, A., T. Tekalign and D. Nigussie. 2009. Response of potato (Solanum tuberosum L.) to different rates of nitrogen and phosphorus fertilization on vertisols at Debre Berhan, in the central highlands of Ethiopia. African Journal of Plant Science 3: 16-24. 